\title{
PENGARUH GAYA KEPEMIMPINAN \\ TRANSFORMASIONAL DAN BUDAYA ORGANISASI \\ TERHADAP KINERJA PEGAWAI DENGAN KOMITMEN \\ ORGANISASI SEBAGAI VARIABEL INTERVENING (Studi pada PNS di Kecamatan Watukumpul Kabupaten \\ Pemalang)
}

\author{
Oleh : \\ Ahmad Mubarak ${ }^{1}$ Susetyo Darmanto ${ }^{2}$ \\ Fakultas Ekonomika dan Bisnis UNTAG Semarang \\ Email : susetyodarmanto@yahoo.co.id
}

\begin{abstract}
This study aimed to determine the effect of transformational leadership style on performance and organizational commitment as an intervening variable, the influence of organizational culture on employee performance and organizational commitment as an intervening variable, determine the effect of transformational leadership style directly to employee performance, and determine the influence of organizational culture directly to the employee performance. The population in this study were all employees of the Watukumpul districtl. By using the census method, all employees amounted to 140 people were carried out as the sample. Analysis data were analyzed using path analysis. Based on the research results it could be concluded that there was significantly and positive effect of transformational leadership style and organizational culture. Transformational leadership style and organizational culture also had significantly and positive effect on Organizational commitment. And finally there was significantly and positive effect of organiztional commitment.The research also showed that Organizational commitment had a mediating role between transformational leadership style, Organizational culture and employee performance.
\end{abstract}

Keyword: Transformational Leadership Style, Cultural Organization,Organizational Commitment, Employee Performance 


\section{PENDAHULUAN \\ Latar Belakang Masalah}

Perubahan lingkungan organisasi yang semakin kompleks dan kompetitif, menuntut setiap organisasi dan perusahaan untuk bersikap lebih responsif agar sanggup bertahan dan terus berkembang. Menurut Gomes (2003) secara garis besar perbedaan kinerja ini disebabkan oleh dua faktor, yaitu: faktor individu dan situasi kerja. Ada tiga perangkat variabel yang mempengaruhi perilaku dan prestasi kerja atau kinerja, yaitu:variable individu, variable organisasional, dan variable psikologis

Schein (1992), Nahavandi \& Malekzadeh (1993) serta Kouzes \& Posner (1987) juga menyatakan bahwa kepemimpinan adalah faktor individu yang mempunyai pengaruh besar terhadap keberhasilan organisasi. Menurut Geerts (1994) pemimpin adalah sebagai panutan dalam organisasi, sehingga perubahan harus dimulai dari tingkat yang paling atas yaitu pemimpin itu sendiri. Maka dari itu, organisasi memerlukan pemimpin reformis yang mampu menjadi motor penggerak yang mendorong perubahan organisasi. Sampai saat ini, kepemimpinan masih menjadi topik yang menarik untuk dikaji dan diteleti, karena paling sering diamati namun merupakan fenomena yang sedikit dipahami (Yukl, 1995). Dalam dunia bisnis, gaya kepemimpinan berpengaruh kuat terhadap jalannya organisasi dan kelangsungan hidup organisasi (Schein, 1992). Peran kepemimpinan sangat strategis dan penting dalam sebuah organisasi sebagai salah satu penentu keberhasilan dalam pencapaian misi, visi dan tujuan suatu organisasi. Sehingga, tantangan dalam mengembangkan strategi organisasi yang jelas terutama terletak pada organisasi di satu sisi dan kepemimpinan. Sukses tidaknya suatu tujuan yang dicapai sebuah organisasi tergantung dari pemimpin (Yukl, 1995). Bass (1990) menyatakan bahwa kualitas dari pemimpin sering kali dianggap sebagai faktor terpenting yang menentukan keberhasilan atau kegagalan organisasi.

Budaya organisasi dan kepemimpinan telah secara independen dihubungkan dengan kinerja instansi . Para peneliti telah menguji hubungan antara gaya kepemimpinan dan kinerja dan juga antara budaya perusahaan dan kinerja (Bass, 1985). Dalam praktek-prakteknya, budaya organisasi mengacu pada nilai-nilai dan keyakinan yang terkait dengan sistem operasional yang dilakukan oleh sebuah organisasi. Budaya organisasi adalah penting untuk menyediakan konsistensi dan fleksibilitas agar bisa responsif terhadap permintaan pelanggan, dan untuk mencapai keunggulan kompetitif yang berkelanjutan, budaya belajar ditemukan menjadi kemampuan organisasi yang sangat penting.Demikian pula halnya dengan birokrasi publik, pemimpin memegang peranan yang sangat strategis. Berhasil atau tidaknya birokrasi publik menjalankan tugas-tugasnya sangat ditentukan oleh kualitas pimpinannya, karena kedudukan pemimpin sangat mendominasi semua aktivitas yang dilakukan.

Walapun demikian dalam beberapa penelitian sebelumnya, masih terdapat perbedaan hasil penelitian tentang pengaruh kepemimpinan, budaya organisasi dan komitmen organisasi terhadap Kinerja organisais.

Berdasarkan hasil penelitian dan pembahasan yang dilakukan oleh Hasanuddin (2011), dihasilkan beberapa kesimpulan bahwa kinerja organisasi merupakan hasil kerja yang secara kualitas dan kuantitas dapat dicapai oleh suatu organisasi dalam melaksanakan semua kegiatan pokok sehingga mencapai misi atau visi organisasi. Pencapaian kinerja organisasi akan dipengaruhi oleh faktor kepemimpinan dan komitmen organisasi. Adapun faktor budaya organisasi yang dibangun dalam model penelitian ini tidak mempengaruhi baik motivasi kerja maupun kinerja organisasi pada Badan Perencanaan Pembangunan Daerah Kabupaten Aceh Besar. Penelitian serupa juga dilakukan oleh Widodo (2011) tentang pengaruh gaya kepemimpinan, budaya organisasi, dan motivasi kerja terhadap kinerja guru.. Dari ketiga variabel independen, motivasi kerja memiliki pengaruh paling besar terhadap kinerja. Adapun berdasarkan penelitian yang dilakukan oleh Bagus (2010), didapat simpulan bahwa budaya organisasi, gaya kepemimpinan motivasi berpengaruh positif dan signifikan terhadap kinerja pegawai di Cipaganti Group. Berdasarkan hasil analisis yang dilakukan oleh Rahmawati (2012), disimpulkan bahwa: 1) Budaya organisasi berpengaruh secara positif dan signifikan dengan kinerja dosen. Budaya organisasi menunjukkan tingkat yang tinggi. Hal ini nilai-nilai seperti inisiatif individual, toleransi terhadap tindakan berisiko, identitas dan toleransi terhadap konflik 
sudah melembaga dengan baik; 2) Gaya Kepemimpinan berpengaruh secara positif dan signifikan dengan kinerja dosen. Gaya Kepemimpinan menunjukkan tingkat yang tinggi. Karena saat ini unit organisasi fakultas sudah dipimpin oleh pemimpin yang berorientasi prestasi dan menekankan nilai-nilai kemanusiaan. Memberi kesempatan kepada bawahan untuk bertukar ide. Penelitian lain seperti yang dilakukan oleh Fajra (2011) bahwa pada pimpinan Badan Kepegawaian Daerah Kabupaten Agam lebih dominan pada gaya kepemimpinan transformasional daripada gaya kepemimpinan transaksional. Secara parsial gaya kepemimpinan yaitu kepemimpinan transformasional berpengaruh negatif dan tidak signifikan terhadap kinerja pegawai . Kemudian budaya perusahaan berpengaruh negatif dan tidak signifikan terhadap kinerja pegawai . Dengan demikian penelitian ini membantu pimpinan/kepala kantor dalam memahami apa saja hal-hal yang dapat meningkatkan kinerja para pegawai pada Badan Kepegawaian Daerah kabupaten Agam.

Kecamatan Watukumpul adalah salah satu dari 14 Kecamatan yang ada di wilayah Kabupaten Pemalang, yang membawahi 15 Desa. Secara geografis wilayah Kecamatan Watukumpul berada di daerah pegunungan/perbukitan, dengan kondisi infrastruktur jalan yg cukup memprihatinkan. Sebagai suatu Satuan Kerja Perangkat Daerah (SKPD), Kantor Kecamatan Watukumpul memiliki 20 orang pegawai dengan rincian 14 orang berstatus PNS sedangkan lainnya masih berstatus tenaga honorer. Dengan pegawai yang hanya sejumlah 20 orang tersebut, yang memiliki kemampuan dan karakter bervariatif, maka akan cukup berat untuk menanggung beban kerja yang begitu besar. Untuk itu dituntut kinerja yang maksimal dari seluruh personil yang ada untuk melaksanakan berbagai tugas pokok, tugastugas tambahan sebagai konsekwensi dari pelimpahan sebagian kewenangan Bupati kepada Camat di dalam rangka efektifitas \& efisiensi kerja dan mendekatkan pelayanan kepada masyarakat, serta tugas-tugas tambahan lainnya dalam rangka membantu pelaksanaan tugas-tugas SKPD tehnis.

Berdasarkan latar belakang masalah yang diuraikan tersebut, permasalahan penelitian yang diajukan dalam penelitian ini adalah : Bagaimana pengaruh gaya kepemimpinan transformasional dan budaya organisasi terhadap kinerja pegawai dengan komitmen orhanisasi sebagai variable intervening kantor kecamatan Watukumpul?

\section{Tujuan Penelitian}

Adapun tujuan dari penelitian ini adalah sebagai berikut

a. Untuk mengetahui pengaruh gaya kepemimpinan transformasional terhadap kinerja pegawai kantor kecamatan Watukumpul

b. Untuk mengetahui pengaruh budaya organisasi terhadap kinerja pegawai kantor kecamatan Watukumpul

c. Untuk mengetahui pengaruh gaya kepemimpinan transformasional terhadap Komitmen Organisasi Kantor Kecamatan Watukumpul

d. Untuk mengetahui pengaruh budaya organisasi terhadap Komitmen Organisasi Kantor Kecamatan Watukumpul

e. Untuk mengetahui pengaruh Komitmen Organisasi terhadap Kinerja Pegawai Kantor Kecamatan Watukumpul

\section{TELAAH PUSTAKA DAN PENGEMBANGAN MODEL PENELITIAN}

Gaya Kepemimpinan Transformasional

Kepemimpinan transformasional merupakan antitesis dari model kepemimpinan yang ingin mempertahankan status quo, sehingga kepemimpinant transformasional dapat didefinisikan sebagai kepemimpinan yang mencakup upaya perubahan organisasi (Dwiyekti, 2011). Khan, et al (2012) mengatakan bahwa transformasional adalah dimana pengikut lebih diberikan kebebebasan, rasa kepemilikan dan tanggung jawab yang memungkinkan para pengikut untuk mengembangkan kemampuan kepemimpinan dan tujuan akhirnya meningkat. Luthans (2006) menyatakan bahwa kepemimpinan transformasional membawa keadaan menuju kinerja tinggi pada organisasi yang menghadapi tuntutan pembaharuan dan perubahan. Kepemimpinan transformasional merupakan kemampuan untuk memberikan inspirasi dan memotivasi para pengikutnya untuk mencapai hasil - hasil yang lebih besar daripada yang direncanakan secara orisinil dan untuk imbalan internal (Mondiani, 2012). Para pemimpin transformasional, mempengaruhi para pengikut dengan 
menimbulkan emosi yang kuat dan indentifikasi dengan pemimpin tersebut, namun mereka dapat juga mentransformasi para pengikut dengan bertindak sebagai seorang pelatih, guru atau mentor. Para pemimpin transformasional mencoba untuk memberi kekuasaan dan meninggikan para pengikut. Para pemimpin transformasional dapat ditemukan dalam organisasi mana saja pada tingkatan dimana saja. Kepemimpinan transformasional juga mengembangkan setiap orang menjadi self leadership. Kepemimpinan transformasional adalah pemimpin yang memimpin orang lain untuk memimpin diri mereka sendiri.

\section{Budaya Organisasi}

Menurut Robbins (2006), budaya organisasi merupakan suatu persepsi bersama yang dianut oleh anggota-anggota organisasi, dan merupakan suatu sistem makna bersama. Sehingga budaya yang tumbuh menjadi kuat mampu memacu organisasi kearah perkembangan yang lebih baik. Budaya organisasional adalah sistem makna, nilai-nilai dan kepercayaan yang dianut bersama dalam suatu organisasi yang menjadi rujukan untuk bertindak dan membedakan organisasi satu dengan organisasi lain. Budaya organisasi selanjutnya menjadi identitas atau karakter utama organisasi yang dipelihara dan dipertahankan (Mas'ud, 2004). Budaya mempunyai kekuatan untuk mempengaruhi organisasi, ia akan mempengaruhi setiap hal dari siapa yang dipromosikan dan keputusan apa yang dibuat. Kadang-kadang budaya tersebut terpecah-pecah dan sulit untuk dibaca dari luar. Budaya organisasi juga sangat kuat dan potensif, setiap orang mengetahui tujuan organisasi dan mereka bekerja untuk mencapainya. Melihat dampak itu, budaya juga mempunyai pengaruh yang besar terhadap suksesnya suatu bisnis, dan untuk menarik garis antara penelitian dan penelitian budaya organisasi lainnya, penelitian ini hanya mempertimbangkan praktek-praktek budaya organisasi yang terkait dengan respons, yang telah dibahas pada bagian sebelumnya.

\section{Komitmen Organisasi}

Luthans (2006) mendefinisikan komitmen organisasi sebagai sikap yang merefleksikan loyalitas pegawai pada organisasi dan proses berkelanjutan dimana anggota organisasi mengekspresikan perhatiannya terhadaporganisasi dan keberhasilan serta kemajuan yang berkelanjutan. Para pegawai yang memiliki idealisme yang cukup tinggi dan percaya terhadap nilai - nilaiperusahaan tempat mereka bekerja memiliki potensi besar untuk bekerja padaperusahaan tersebut sampai mereka pensiun. Kesamaan nilai individu denganperusahaan akan menimbulkan kepuasan batin pada pegawai sehingga secaraotomatis memunculkan rasa memiliki yang tinggi terhadap perusahaan. Hal iniakan berdampak kepada kinerja pegawai tersebut karena tidak ada beban ketika melaksanakan pekerjaannya, kecuali terjadi pergeseran nilai - nilai perusahaan. Porter, et al (1974) dalam Choong, et al (2012) mendefinisikan komitmen organisasi sebagai keyakinan yang kuat dan penerimaan pada tujuan dan nilai-nilai organisasi, kemauan untuk mengerahkan usaha yang cukup atas nama organisasi, dan keinginan yang kuat untuk tetap dalam organisasi. Robbins (2003) mendefinisikan komitmen organisasional sebagai suatu keadaan dimana seorang pegawai memihak pada suatu organisasi tertentu dan tujuan tujuannya serta berniat memelihara keanggotaan dalam organisasi itu. Hal ini berdampak ketika seorang pegawai sedang menghadapi kondisi akan suatu pilihan di lingkungan eksternal, pegawai tersebut akan cenderung berpola pikir seperti perusahaan tempat dia bekerja dan secara implisit akan menunjukkan keberpihakannya atas keunggulan - keunggulan perusahaan tempat dia bekerja. Implikasi lainnya adalah seorang pegawai akan merasa memiliki tanggung jawab untuk mengembangkan perusahaannya dan dapat dilakukan dengan pengembangan kapasitas orang yang berada pada subordinatnya. Adeoye dan Torubelli (2011) berpendapat pegawai yang menunjukkan komitmen organisasi yang tinggi mungkin lebih bahagia dalam pekerjaan mereka, menghabiskan lebih sedikit waktu untuk meninggalkan pekerjaan mereka dan lebih sedikit kecenderungan untuk meninggalkan organisasi.

\section{Kinerja Pegawai}

Kinerja atau prestasi kerja merupakan sebagai kesuksesan seseorang di dalam melaksanakan suatu pekerjaan (Rivai, 2006). Sedangkan Gomes (2003) menyatakan bahwa kinerja atau prestasi kerja seorang pegawai pada dasarnya adaiah hasil kerja seseorang pegawai selama periode tertentu dibandingkankan dengan kemungkinan, misalnya standar, target/sasaran atau kinerja yang telah ditentukan terlebih dahulu dan telah di 
sepakati bersama. Menurut Mangkunegara (2007), tingkat sejauh mana keberhasilan seseorang dalam menyelesaikan pekerjaannya disebut "level of performance". Biasanya orang yang level of performance-nya tinggi disebut sebagai orang yang produktif, dan sebaliknya orang yang levelnya tidak mencapai standar dikatakan sebagai tidak produktif atau berperformance rendah. Penilaian kinerja adalah salah satu tugas penting untuk dilakukan oleh seorang manajer atau

\section{Kerangka Pemikiran}

Adapun kerangka pemikiran teoretis yang dibuat oleh peneliti adalah sebagai berikut: pimpinan. Walaupun demikian, pelaksanaan kinerja yang obyektif bukanlah tugas yang sederhana.. Dalam penilaian harus dihindarkan adanya "like dan dislike" dari penilai, agar obyektifitas penilaian dapat terjaga. Kegiatan penilaian ini penting, karena dapat digunakan untuk memperbaiki keputusan-keputusan personalia dan memberikan umpan balik kepada para pegawai tentang kinerja mereka.

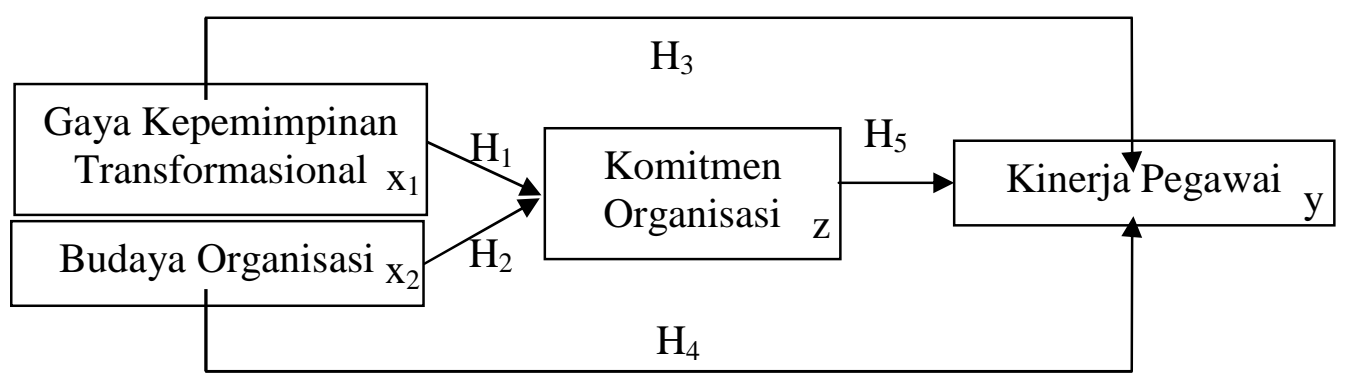

Gambar 1

\section{Hipotesis}

Berdasar data-data yang penulis himpun, maka hipotesisnya adalah :

$\mathrm{H}_{1}$ : Gaya Kepemimpinan Transformasional berpengaruh positif dan signifikan terhadap Kinerja Pegawai dengan Komitmen Organisasi sebagai variabel intervening.

$\mathrm{H}_{2}$ : Budaya Organisasi berpengaruh positf dan signifikan terhadap kinerja pegawai dengan komitmen organisasi sebagai variabel intervening.

. $\mathrm{H}_{3}$ : Gaya Kepemimpinan Transformasional berpengaruh positif dan signifikan terhadap Kinerja Pegawai .

$\mathrm{H}_{4}$ : Budaya Organisasi berpengaruh positif dan signifikan terhadap Kinerja Pegawai .

H5 : Komitmen Organisasi berpengaruh positif dan signifikan terhadap Kinerja Pegawai .

\section{METODE PENELITIAN \\ Definisi Operasional dan Indikator Variabel}

Kinerja pegawai diartikan sebagai hasil kerka baik kualitas maupun kuantitas yang dicapai oleh seseorang dalam

\section{Pemikiran Teoritis}

melaksanakan tugas sesuai tanggung jawab yang diberikan (Mangkunegaran, 2007). Indikator penelitiannya meliputi : Kuantitas Kerja pegawai , kualitas Kerja pegawai, standart Profesional, kreativitas pegawai.

Komitmen organisasi diartikan suatu keadaan dimana seorang pegawai memihak pada suatu organisasi tertentu dan tujuan - tujuannya serta berniat memelihara keanggotaan dalam organisasi (Robbins, 2006). Indikator penelitiannya meliputi : Perasaan emosional pegawai dengan organisasi dimana diaberkontribusi, makna perusahaan untuk seorang pegawai, rasa puas dan senang akan tempat dia berkontribusi, rasa cinta dan loyal pegawai untuk membanggakan organisasi, sikap tanggung jawab pegawai untuk penyelesaian masalah organisasi.

Kepemimpinan transformasional
merupakan antitesis dari model kepemimpinan yang ingin mempertahankan status quo, sehingga kepemimpinan transformasional dapat didefinisikan sebagai kepemimpinanyang mencakup upaya perubahan organisasi (Dwiyekti, 2011). Indikator penelitiannya terdiri dari : pengaruh teridealkan, motivasi terinspirasikan, rangsangan intelektual, pertimbangan individu. 
Budaya orgaisasi adalah diartikan sebagai suatu cognitive framework yang meliputi sikap, nilai-nilai, norma perilaku dan harapan-harapan yang disumbangkan anggota organisasi (Stoner, 1995). Indikator penelitiannya meliputi : Profesionalisme, percaya pada rekan sekerja, keteraturan.

\section{Populasi dan Sampel}

Dalam penelitian ini, yang menjadi populasi adalah seluruh pegawai kantor kecamatan Watukumpul. Pengambilan sampel dilakukan dengan metode sampling jenuh yaitu seluruh sampel yang ada di dalam suatu populasi karena menurut Arikunto (2006:78) jika jumlah anggota subjek dalam populasi hanya meliputi 110 hingga 150 dan dalam pengumpulan data menggunakan angket, sebaiknya subjek sejumlah itu diambil seluruhnya. Mengingat jumlah pegawai kantor kecamatan Watukumpul berjumlah kurang dari 140 orang, maka jumlah sampel yang akan digunakan meliputi seluruh pegawai kantor kecamatan Watukumpul

\section{Analisis Data}

Penelitian ini menggunakan model analisis jalur (path analysis) dengan menggunakan pendekatan model regresi linier berganda. Hubungan variabel gaya kepemimpinan transformasional dan budaya organisasi terhadap kinerja pegawai yang dimediasi komitmen organisasi digambarkan dalam path analysis sebagai berikut.

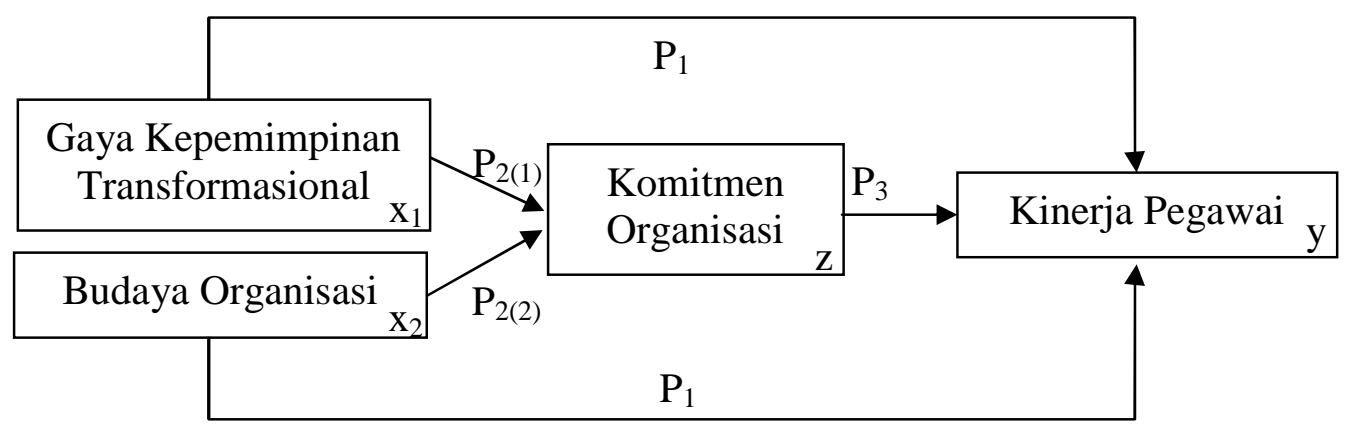

Gambar 2

Keterangan :

- Pengaruh langsung $\left(\mathrm{X}_{1}, \mathrm{X}_{2}\right.$ terhadap $\left.\mathrm{Y}\right)$

$=\mathrm{P} .1$

- $\quad$ Pegaruh tidak langsung melalui $\left(\mathrm{X}_{1}, \mathrm{X}_{2}\right.$, terhadap $\mathrm{Z}$ dan $\mathrm{Z}$ terhadap Y) $=$ P.2 $\times$ P.3

- Total Pengaruh $=$ P. $1+(P .2 x$ P.3)

Dari gambar diatas dapat dijelaskan bahwa Gaya Kepemimpinan Transformasional dan Budaya Organisasi dapat berpengaruh langsung terhadap kinerja pegawai (P.1), tetapi dapat juga dapatberpengaruh tidak langsung, yaitu dengan melalui intervening komitmen organisasi (P.2), baru kemudian dari komitmen kerja ke kinerja pegawai (P.3).

\section{HASIL PENELITIAN DAN}

\section{PEMBAHASAN}

Pengujian Validitas dan Reliabilitas
Instrumen
Uji Valitidas

\section{Path Analysis}

Uji validitas digunakan untuk menguji sejauh mana ketepatan alat pengukur dapat mengungkapkan konsep gejala/ kejadian yang diukur. Pengujian validitas dilakukan dengan menggunakan rumus korelasi product moment. Pengujian validitas menunjukan bahwa semua indikator yang digunakan untuk mengukur variabel-variabel yang digunakan dalam penelitian ini mempunyai koefisien korelasi ( $r$ hitung) yang lebih besar dari nilai $r$ tabel two tail untuk $\mathrm{DF}_{\mathrm{n}-2}={ }_{140-2}=138$ uji dua sisi dengan signifikansi $5 \%$ adalah 0,166 . Dengan demikian dapat nyatakan semua indikator tersebut adalah valid dan tidak ada yang gugur.

\section{Uji Reliabitas}

Uji reliabilitas digunakan untuk menguji sejauh mana keandalan suatu alat pengukur untuk dapat digunakan lagi untuk penelitian yang sama. Pengujian reliablitas ini adalah dengan menggunakan rumus Alpha. Hasil pengujian reliabilitas untuk masing - masing variabel yang diringkas pada tabel 4.6 berikut. 
Tabel 1

Hasil Pengujian Reliabilitas

\begin{tabular}{|l|c|c|}
\hline \multicolumn{1}{|c|}{ Variabel } & Alpha & Keterangan \\
\hline G.K. Transformasional & 0,863 & Reliabel \\
\hline Budaya Organisasi & 0,759 & Reliabel \\
\hline Komitmen Organisasi & 0,821 & Reliabel \\
\hline Kinerja Pegawai & 0,783 & Reliabel \\
\hline
\end{tabular}

Sumber: data primer yang diolah, 2014

Hasil uji reliabel pada Tabel 4.6 tersebut di atas menunjukan bahwa semua variabel mempunyai koefisien alpha yang cukup besar yaitu di atas 0,60 sehingga dapat dikatakan semua konsep pengukur masing - masing variabel dari kuesioner adalah reliabel atau konsistensehingga layak digunakan sebagai alat ukur penelitian.

\section{Uji Asumsi Klasik}

Penelitian ini menggunakan model analisis jalur (path analysis) dengan menggunakan pendekatan model regresi linier berganda. Suatu model regresi yang baik harus bebas dari masalah penyimpangan terhadap asumsi klasik. Berikut ini adalah hasil pengujian asumsi klasik kedua persamaan regresi.

\section{Uji Normalitas}

Pengujian normalitas dilakukan dengan menggunakan pengujian terhadap nilai residual. Sedangkan pengujian dilakukan dengan menggunakan Grafik Histogram dan P-P Plot. Berdasarkan grafik histogram di atas dapat diketahui bahwa residual regresi mengikuti kurva normalnya. Sedangkan pada grafik normal P-P Plot Regression menunjukan bahwa titik residual model regresi sudah berdistribusi normal karena titik titik tersebut menyebar disekitar garis diagonal. Dengan demikian syarat distribusi normal sebagai pengujian statistik dengan menggunakan regresi dapat terpenuhi.

\section{Pengujian Multikolinieritas}

Suatu variabel menunjukan gejala multikolinieritas bisa dilihat dari nilai VIF (Variance Inflation Factor) yang tinggi pada variabel - variabel bebas suatu model regresi. Nilai VIF yang lebih besar dari 10 menunjukan adanya gejala multikolinieritas dengan model regresi. Hasil pengujian VIF dari model regesi menunjukan bahwa semua variabel yang digunakan sebagai prediktor model regresi menunjukan nilai VIF yang semuanya berada dibawah angka 10 . Hal ini berarti bahwa variabel - variabel bebas yang digunakan dalam penelitian tidak menunjukan adanya gejala multikolinieritas, yang berarti bahwa variabel bebas dapat digunakan sebagai variabel independen sebagai prediktor yang independen.

\section{Pengujian Heteroskedastisitas}

Uji heteroskedastisitas digunakan untuk mengetahui apakah penaksir yang diperoleh efisien atau tidak, baik dalam sampel kecil maupun dalam sampel besar. Uji heteroskedastisitas juga dapat digunakan untuk mendeteksi apakah antar variabel penelitian saling berpengaruh tanpa didukung dengan rujukan teori yang sudah ada. Deteksi untuk mengetahui apakah model terdapat penyimpangan heteroskedastisitas atau tidak adalah dengan pendekatan grafik scatterplot.

Hasil pengujian heteroskedastisitas menunjukkan tidak ada satupun variabel bebas yang signifikan berhubungan dengan nilai mutlak residual. Hal ini berarti bahwa model regresi tidak memiliki gejala adanya heteroskedastisitas. Dengan demikian menunjukkan bahwa gangguan variabel (error) dari penelitian ini tidak memiliki hubungan yang signifikan dengan variabelvariabel bebasnya, yang berarti bahwa gangguan variabel (error) dari penelitian ini memiliki varian atau variasi yang homogen untuk setiap sampelnya.

\section{Uji Goodness Fit of Model}

\section{Analisis Regresi Linier Berganda}

Penelitian ini menggunakan model analisis regresi linier untuk pembuktian hipotesis penelitian. Analisis ini menggunakan input berdasarkan data yang diperoleh dari kuesioner. Perhitungan statistik dalam analisis regresi linier berganda yang digunakan dalam penelitian ini adalah dengan menggunakan bantuan program SPSS for Windows versi 16. Hasil 
pengolahan data dengan menggunakan data

SPSS selengkapnya sebagai berikut.

Tabel 2.

Hasil Analisis Regresi Linier Berganda

Persamaan Regresi Pertama

\begin{tabular}{|c|c|c|c|c|c|}
\hline \multirow[b]{2}{*}{ Model } & \multicolumn{2}{|c|}{ Unstandardized Coefficients } & \multirow{2}{*}{$\begin{array}{c}\begin{array}{c}\text { Standardized } \\
\text { Coefficients }\end{array} \\
\text { Beta }\end{array}$} & \multirow[b]{2}{*}{$\mathrm{t}$} & \multirow[b]{2}{*}{ Sig. } \\
\hline & B & Std. Error & & & \\
\hline 1 (Constant) & 11.708 & 1.978 & & 5.919 & .000 \\
\hline GK Transformasional & .257 & .071 & .289 & 3.611 & .000 \\
\hline Budaya Organisasi & .272 & .111 & .196 & 2.451 & .015 \\
\hline
\end{tabular}

a. Dependent Variable: Komitmen Organisasi

Model persamaan regresi yang dapat dituliskan dari hasil tersebut dalam bentuk persamaan regresi pertama bentuk standar adalah sebagai berikut:

Komitmen Organisasi $=0,289$ GK

Transformasional + 0,196 B. Organisasi

Persamaan regresitersebut dapat dijelaskan sebagai berikut :
- Koefisien regresi Gaya Kepemimpinan Transformasional sebesar 0,289 menjelaskan bahwa setiap perbaikan gaya kepemimpinan transformasional akan meningkatkan komitmen pegawai pada organisasi.

- Koefisien regresi Budaya Organisai sebesar 0,196 menjelaskan bahwa setiap perbaikan budaya organisasi akan meningkatkan komitmen pegawai pada organisasi.

Tabel 3

Hasil Analisis Regresi Linier Berganda Persamaan Regresi Kedua

\begin{tabular}{|c|c|c|c|c|c|}
\hline \multirow[b]{2}{*}{ Model } & \multicolumn{2}{|c|}{$\begin{array}{l}\text { Unstandardized } \\
\text { Coefficients }\end{array}$} & \multirow{2}{*}{$\begin{array}{c}\begin{array}{c}\text { Standardized } \\
\text { Coefficients }\end{array} \\
\text { Beta }\end{array}$} & \multirow[b]{2}{*}{$\mathrm{T}$} & \multirow[b]{2}{*}{ Sig. } \\
\hline & $\mathrm{B}$ & Std. Error & & & \\
\hline $1 \quad$ (Constant) & .345 & 1.805 & & .191 & .849 \\
\hline GK Transformasional & .255 & .061 & .305 & 4.219 & .000 \\
\hline Budaya Organisasi & .413 & .092 & .316 & 4.472 & .000 \\
\hline Komitmen Organisasi & .241 & .070 & .256 & 3.461 & .001 \\
\hline
\end{tabular}

Model persamaan regresi kedua yang dapat dituliskan dari hasil tersebut dalam bentuk persamaan regresi bentuk standar adalah sebagai berikut:

Kinerja Pegawai = 0,305 Gaya

Kepemimpinan Transformasional + 0,316

Budaya Organisasi + 0,256 Komitmen

Organisasi

\section{Uji Model (Uji Statistik F)}

Hasil uji statistik Fmenggunakan program SPSS dapat dilihat pada tabel berikut.

Tabel 4.

Hasil Uji F Persamaan Regresi 1

ANOVA

\begin{tabular}{|ll|r|r|r|r|r|}
\hline Model & Sum of Squares & Df & Mean Square & F & \multicolumn{1}{c|}{ Sig. } \\
\hline 1 & Regression & 101.792 & 2 & 50.896 & 10.117 & $.000^{\mathrm{a}}$ \\
& Residual & 689.180 & 137 & 5.031 & & \\
& Total & 790.971 & 139 & & & \\
\hline
\end{tabular}

Sumber : Data Primer yang diolah, 2014 
Dari hasil uji $F$ di atas dapat diketahui bahwa nilai probabilitas $0,000<$ 0,05, sehingga keputusannya adalah menolak Ho1 danmenerima hipotesis alternatif (Ha1). Hal ini berarti Gaya
Kepemimpinan Transformasional dan Budaya Organisasi mempunyai pengaruh yang signifikan terhadap Komitmen Organisasi.

Tabel 5.

Hasil Uji F Persamaan Regresi 2

ANOVA $^{b}$

\begin{tabular}{|ll|r|r|r|r|r|}
\hline Model & & Sum of Squares & Df & Mean Square & \multicolumn{1}{c|}{ F } & \multicolumn{1}{c|}{ Sig. } \\
\hline 1 & Regression & 101.792 & 2 & 50.896 & 10.117 & $.000^{\mathrm{a}}$ \\
& Residual & 689.180 & 137 & 5.031 & & \\
& Total & 790.971 & 139 & & & \\
\hline
\end{tabular}

Sumber : Data Primer yang diolah, 2014

Dari hasil uji F di atas dapat diketahui bahwa nilai probabilitas $0,000<$ 0,05, sehingga keputusannya adalah menolak Ho2 danmenerima hipotesis alternatif (Ha2). Hal ini berarti Gaya Kepemimpinan Transformasional, Budaya Organisasi, dan Komitmen Organisasi mempunyai pengaruh yang signifikan terhadap Kinerja Pegawai.

\section{Koefisien Determinasi}

Koefisien determinasi pada penelitian ini bertujuan mengukur seberapa jauh kemampuan model dalam menerangkan variasi variabel dependen. Hasil perhitungan SPSS untuk uji koefisien determinasi dapat dijelaskan pada tabel berikut:

Tabel 6.

\section{Hasil Uji Koefisien Determinasi Persamaan Regresi 1}

Model Summary ${ }^{b}$

\begin{tabular}{|l|r|r|r|r|r|}
\hline Model & $\mathrm{R}$ & R Square & $\begin{array}{l}\text { Adjusted R } \\
\text { Square }\end{array}$ & $\begin{array}{l}\text { Std. Error of the } \\
\text { Estimate }\end{array}$ & Durbin-Watson \\
\hline 1 & $.359^{\mathrm{a}}$ & .129 & .116 & 2.243 & 1.900 \\
\hline
\end{tabular}

Sumber : Data Primer yang Diolah, 2014

Dari tampilan output SPSS model summary besarnya $\mathrm{R}^{2}$ adalah 0,129 . Hal ini berarti $12,9 \%$ variasi variabel Komitmen Organisasidapat dijelaskan oleh variabel- variabel independenGaya Kepemimpinan Transformasional dan Budaya Organisasi. Sedangkan sisanya sebesar $87,1 \%$ dijelaskan oleh sebab-sebab yang lain diluar model.

Tabel 7.

Hasil Uji Koefisien Determinasi Persamaan Regresi 2

\begin{tabular}{|r|r|r|r|r|r|}
\hline \multicolumn{1}{|c|}{ Model Summary $^{\mathbf{b}}$} \\
\hline 1 & $\mathrm{R}$ & $\mathrm{R}$ Square & $\begin{array}{c}\text { Adjusted R } \\
\text { Square }\end{array}$ & $\begin{array}{l}\text { Std. Error of the } \\
\text { Estimate }\end{array}$ & Durbin-Watson \\
\hline 1 & $.593^{\mathrm{a}}$ & .352 & .338 & 1.826 & 1.795 \\
\hline
\end{tabular}

Sumber : Data Primer yang Diolah, 2014

Dari tampilan output SPSS model summary besarnya $\mathrm{R}^{2}$ adalah 0,352 . Hal ini berarti 35,2\% variasi variabel Kinerja Pegawaidapat dijelaskan oleh variabelvariabel independenGaya Kepemimpinan Transformasional, Budaya Organisasi dan
Komitmen Organisai. Sedangkan sisanya sebesar $64,8 \%$ dijelaskan oleh sebab-sebab yang lain diluar model.

\section{Uji Hipotesis (Uji t) \\ Uji Hipotesis 1}


Untuk menguji hipotesis pertama dalam penelitian ini,yakni "diduga ada pengaruh positif dari gaya kepemimpinan transformasional terhadap kinerja pegawai dengan komitmen organisasi sebagai variabel intervening", dilakukan dengan sobel test. Hasil output regresi berganda pada persamaan (1) memberikan nilai unstandardize Gaya Kepemimpinan Transformasional sebesar 0,257, dan signifikan pada $0.000<0,05$. Nilai standardize beta 0.289 merupakan nilai path atau jalur p2. Pada output regresi berganda pada persamaan (2) nilai unstandardized untuk gaya kepemimpinan transformasional adalah sebesar 0,255 dan signifikan pada $0,000<0,05, \quad$ sedangkan nilai unstandardized untuk pengaruh komitmen organisasi adalah sebesar 0,241 dan signifikan pada $0,001<0,05$. Nilaistandardize beta sebesar0,305 merupakan nilai jalur p1, sedangkan nilaistandardize beta0.256 merupakan nilai jalur p3. Besarnya e1 $=\sqrt{ }\left(1-\mathrm{R}^{2}\right)=\sqrt{ }(1-0.129)$ $=0,933$, sedangkan besarnya e $2=\sqrt{ }\left(1-\mathrm{R}^{2}\right)=$ $\sqrt{ }(1-0.352)=0,805$. Diagram jalur dapat digambarkan sebagai berikut:

\section{Gambar 3}

Analisis Jalur 1

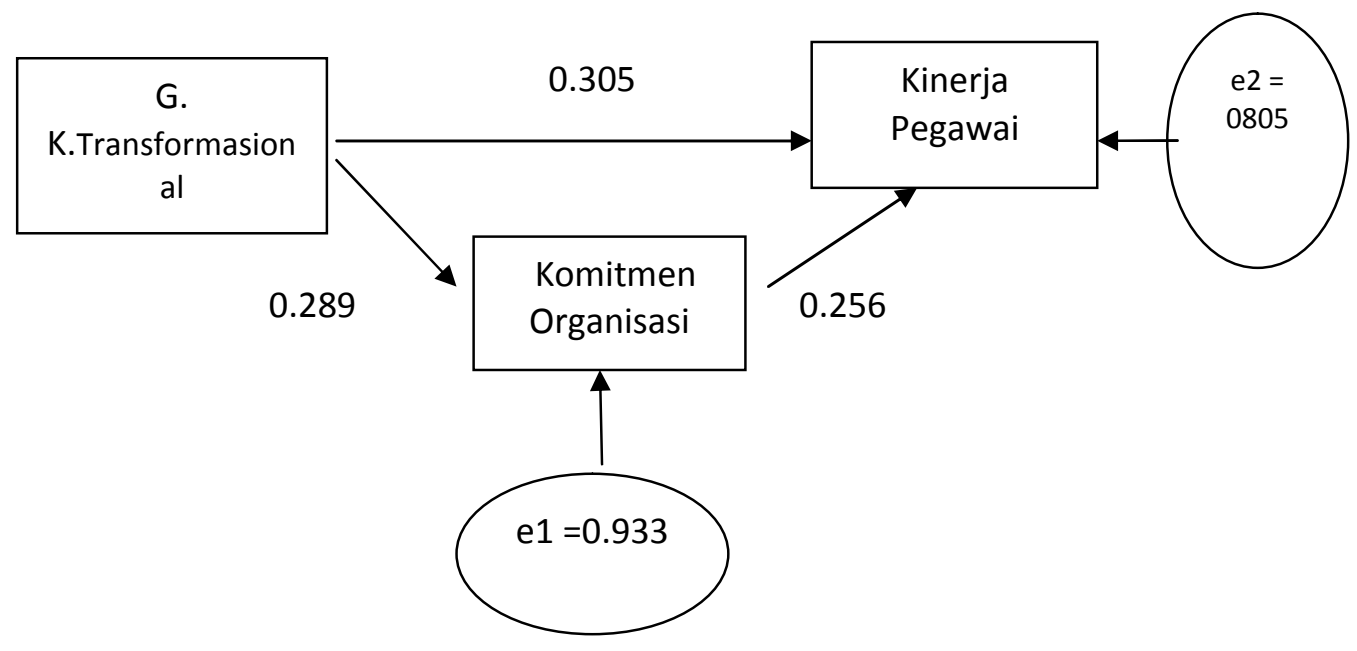

Hasil analisis jalur pertama di atas menunjukkan bahwa Gaya Kepemimpinan Transformasional dapat berpengaruh langsung ke Kinerja Pegawai, dan dapat juga berpengaruh tidak langsung yaitu dari Gaya Kepemimpinan transformasional ke Komitmen Organisasi (sebagai intervening) lalu ke Kinerja Pegawai. Besarnya pengaruh langsung adalah 0.305 sedangkan pengaruh tidak langsungnya adalah $0.289 \times 0.256=$ 0.074 , dan total pengaruh adalah $0.305+$ $0.074=0.379$.

Pengaruh mediasi yang ditunjukkan oleh perkalian koefisien (p2 x p3) sebesar 0.074 signifikan atau tidak, diuji dengan Sobel test yang hasilnya sebagai berikut:

\section{Gambar 4}

\section{Hasil Perhitungan Sobel Test 1}




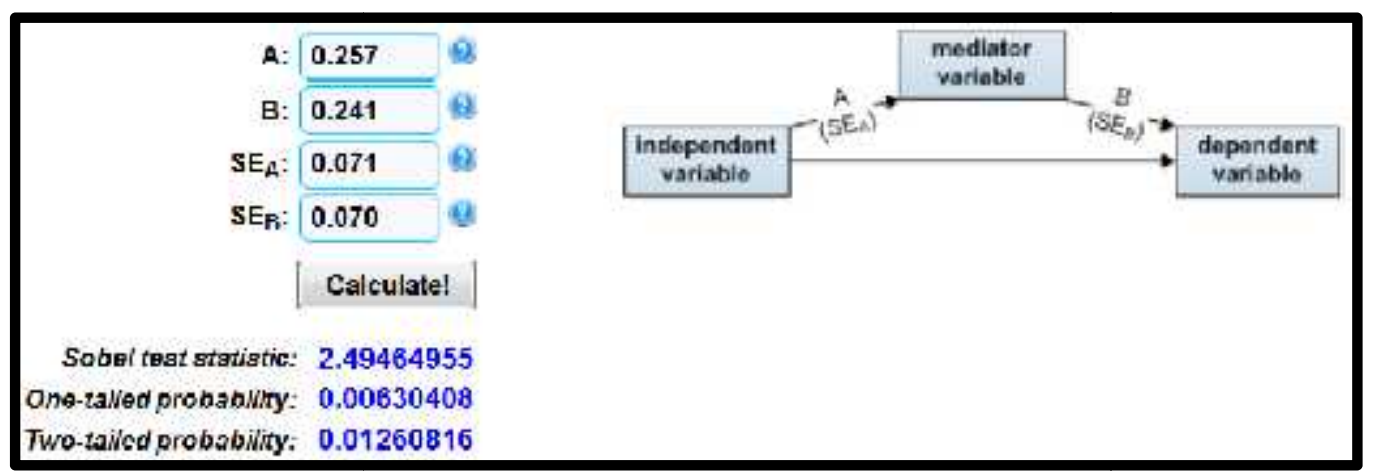

Sumber : http://www.danielsoper.com/statcalc3/calc.aspx $? \mathrm{id}=31$

Oleh karena nilai $\mathrm{t}$ hitung $=2.495>\mathrm{t}$ tabel $\left._{(\alpha}=5 \%\right) 1.96$ dan nilai one-tailed probability sebesar $0,006<0,05$, maka dapat dinyatakan bahwa koefisien mediasi 0.074 adalah signifikan yang berarti ada efek mediasi (intervening). Dengan demikian hipotesis pertama dapat diterima, yakni ada pengaruh positif dari gaya kepemimpinan transformasional terhadap kinerja pegawai dengan komitmen organisasi sebagai variabel intervening.

\section{Uji Hipotesis 2}

Untuk menguji hipotesis kedua dalam penelitian ini,yakni "diduga ada pengaruh positif dari budaya organisasiterhadap kinerja pegawai dengan komitmen organisasi sebagai variabel intervening", juga dilakukan dengan sobel test. Hasil output regresi berganda pada persamaan (1) memberikan nilai unstandardize Budaya Organisai sebesar 0,272, dan signifikan pada $0.015<0,05$ yang berarti Budaya Organisasi mempengaruhi Komitmen Organisai. Nilai standardize beta 0.196 merupakan nilai path atau jalur p2. Pada output regresi berganda pada persamaan (2) nilai unstandardized untuk budaya organisasi adalah sebesar 0,413 dan signifikan pada $0,000<0,05$, sedangkan nilai unstandardized untuk pengaruh komitmen organisasi adalah sebesar 0,241 dan signifikan pada 0,001. Nilaistandardize beta sebesar0,316 merupakan nilai jalur p1, sedangkan nilaistandardize beta0.256 merupakan nilai jalur p3. Besarnya e1 $=\sqrt{ }\left(1-\mathrm{R}^{2}\right)=\sqrt{ }(1-0.129)$ $=0,933$, sedangkan besarnya e $2=\sqrt{ }\left(1-R^{2}\right)=$ $\sqrt{ }(1-0.352)=0,805$. Diagram jalur dapat digambarkan sebagai berikut:

Gambar 5

Analisis Jalur 2

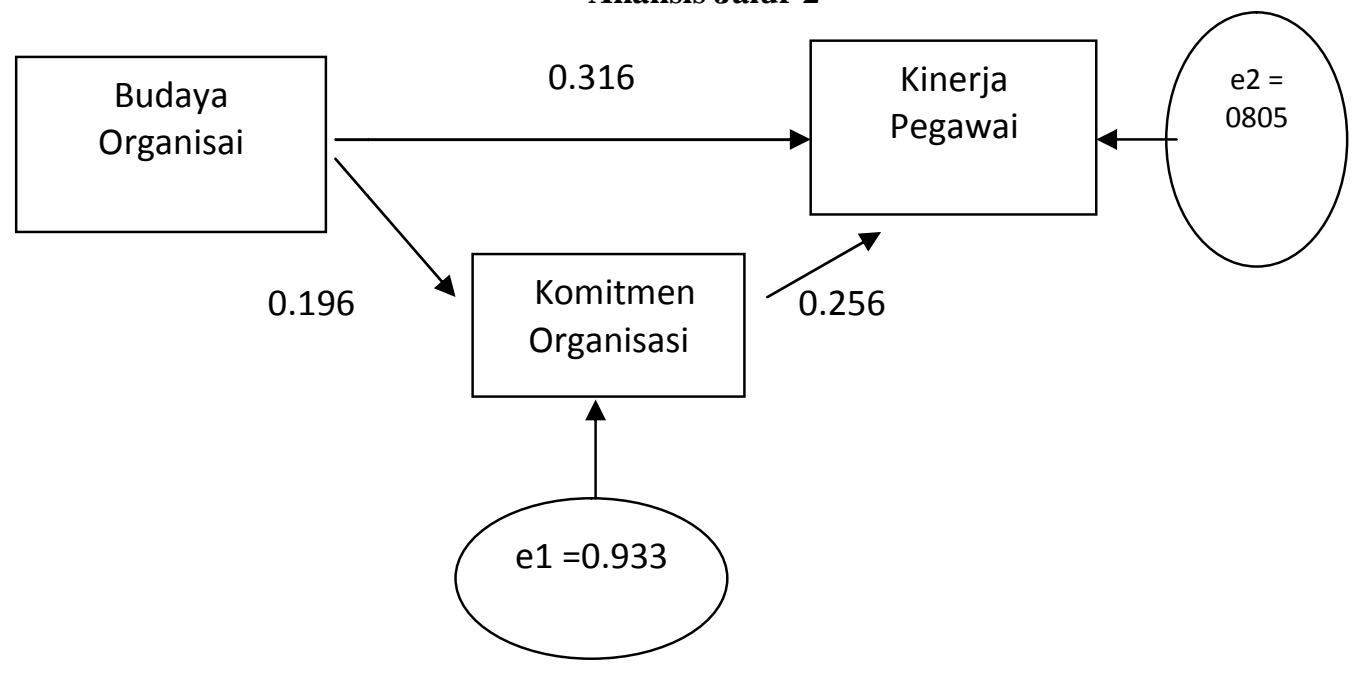


Hasil analisis jalur pertama di atas menunjukkan bahwa Budaya Organisasi dapat berpengaruh langsung ke Kinerja Pegawai, dan dapat juga berpengaruh tidak langsung yaitu dari Budaya Organisasi ke Komitmen Organisasi (sebagai intervening) lalu ke Kinerja Pegawai. Besarnya pengaruh langsung adalah 0.316 sedangkan pengaruh tidak langsungnya adalah $0.196 \times 0.256=$ 0.050 , dan total pengaruh adalah $0.316+$ $0.050=0.366$

Pengaruh mediasi yang ditunjukkan oleh perkalian koefisien (p2 x p3) sebesar 0.050 signifikan atau tidak, diuji dengan Sobel test yang hasilnya sebagai berikut:

\section{Gambar 6}

Hasil Perhitungan Sobel Test 2

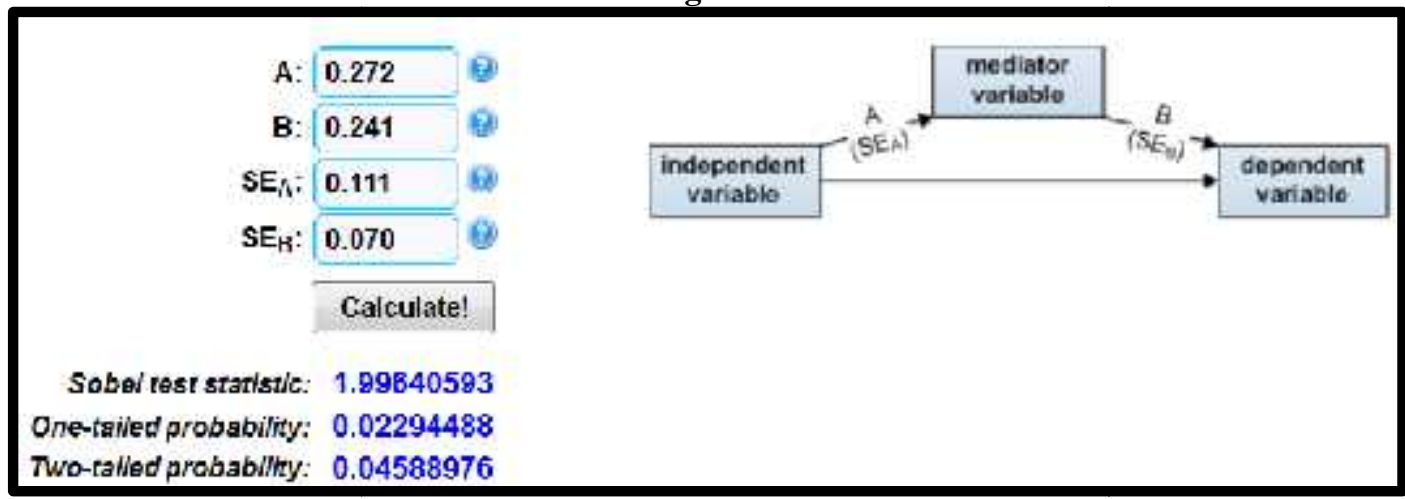

Sumber : http://www.danielsoper.com/statcalc3/calc.aspx $? \mathrm{id}=31$

Oleh karena nilai t hitung $=1,996>\mathrm{t}$ tabel $\left._{(\alpha}=5 \%\right) 1.96$ dan nilai one-tailed probability sebesar $0,022<0,05$, maka dapat dinyatakan bahwa koefisien mediasi 0.050 adalah signifikan yang berarti ada efek mediasi (intervening). Dengan demikian hipotesis kedua dapat diterima, yakni ada pengaruh positif dari budaya organisasi terhadap kinerja pegawai dengan komitmen organisasi sebagai variabel intervening.

\section{Uji Hipotesis 3}

Untuk menguji hipotesis ketiga dalam penelitian ini,yakni "diduga ada pengaruh positif dari gaya kepemimpinan transformasional secara langsung terhadap kinerja pegawai", dilakukan dengan uji t. Dari hasil uji t di atas dapat diketahui bahwa $\mathrm{t}$ hitung sebesar 4,219> 1,96 dengan probabilitas $0,000<0,05, \quad$ sehingga keputusannya adalah menolak Ho dan menerima hipotesis alternatif $\left(\mathrm{H}_{3}\right)$. Arah koefisien regresi yang positif sebesar 0,255 berarti variabel gaya kepemimpinan transformasional berpengaruh langsung positif terhadap kinerja pegawai.

\section{Uji Hipotesis 4}

Untuk menguji hipotesis keempat dalam penelitian ini,yakni "diduga ada pengaruh positif dari budaya organisasi secara langsung terhadap kinerja pegawai”, dilakukan dengan uji t. Dari hasil uji t di atas dapat diketahui bahwa $\mathrm{t}$ hitung sebesar 4,472> 1,96 dengan probabilitas $0,000<$ 0,05, sehingga keputusannya adalah menolak Ho dan menerima hipotesis alternatif $\left(\mathrm{H}_{4}\right)$. Arah koefisien regresi yang positif sebesar 0,413 berarti variabel budaya organisasi berpengaruh langsung positif terhadap kinerja pegawai.

\section{Pengaruh Gaya Kepemimpinan Transformasional Terhadap Kinerja}

Pegawai dengan Komitmen Organisasi Sebagai Variabel Intervening

Hasil dari uji hipotesis pertama pada penelitian ini menyatakan bahwa ada pengaruh positif dari gaya kepemimpinan tranformasionalterhadap kinerja pegawai dengan komitmen organisasi sebagai variabel intervening. Semakin baik gaya kepemimpinan transformasional di terapkan pada Kantor Kecamatan Watukumpul menyebabkan peningkatan pada komitmen pegawai pada organisasi, yang berdampak nyata pada peningkatan kinerjanya. Hasil studi ini mendukung dan membuktikan secara empiris penelitian yang dilakukan oleh Rahmawati (2010), Mondiani (2012),Junchen (2012), Trilaksono (2010), Fajra (2011) dan Widodo (2011) yang menjelaskan bahwa gaya kepemimpinan 
berpengaruh positif dan signifikan terhadap kinerja pegawai. Temuan penelitian ini tidak sejalan dengan hasil riset Hasanuddin (2011) dan Fajra (2011), yang menyebutkan gaya kepemimpinan berpengaruh negatif dan kurang signifikan terhadap kinerja pegawai. Hasil studi ini juga memperkuat hasil penelitian Mondiani (2012) dan Nugroho (2011) yakni komitmen organisasi berpengaruh positif dan signifikan terhadap kinerja pegawai.

Berdasarkan hasil penelitian ini, upaya peningkatan kinerja pegawaidapat ditempuh dengan menumbuhkan komitmen organisasi pegawai, yaitu rasa kecintaan pegawai terhadap organisasi dimana yang bersangkutan bekerja. Hal ini seperti yang dijelaskan oleh Porter, et al (1974) dalam Choong, et al (2012), bahwa komitmen organsiasi merupakan keyakinan yang kuat dan penerimaan pada tujuan dan nilai-nilai organisasi, kemauan untuk menggerakkan usaha yang cukup atas nama organisasi dan keinginan yang kuat untuk tetap dalam organisasi. Komitmen organisasi pegawai yang terdiri atas komitmen afektif, komitmen berkelanjutan, dan komitmen normatif, berdasarkan hasil penelitian ini, dapat ditumbuhkan dengan penerapan gaya kepemimpinan transformasional yang mampu menginspirasi para pegawai untuk mengenyampingkan kepentingan pribadi mereka untuk fokus pada pencapain tujuan organisasi.

\section{Pengaruh Budaya Organisasi Terhadap Kinerja Pegawai dengan Komitmen Organisasi Sebagai Variabel Intervening}

Hasil dari uji hipotesis kedua dalam penelitian ini menyatakan bahwa ada pengaruh positif dari budaya organisasi terhadap kinerja pegawai dengan komitmen organisasi sebagai variabel intervening. Semakin tinggi budaya organisasi dibangun pada Kantor Kecamatan Watukumpul akan berdampak nyata pada peningkatan komitmen pegawai pada organisasi. Hasil dari peningkatan komitmen organsiasi pada akhirnya membawa perbaikan kinerja pegawai. Temuan penelitian ini sejalandengan penelitian sebelumnya yang dilakukan oleh Rahmawati (2012), Fajra (2011), Trilaksono (2010) yang menjelaskan bahwa budaya organisasi berpengaruh positif dan signifikan terhadap kinerja pegawai. Hasil penelitian ini berlawanan dengan hasil riset Fajra (2011), dan
Hasanuddin (2011) yang menunjukkan budaya organisasi bukan faktor penting yang mempengaruhi kinerja pegawai. Hasil studi ini juga memperkuat hasil penelitian Mondiani (2012) dan Nugroho (2011) yakni komitmen organisasi berpengaruh positif dan signifikan terhadap kinerja pegawai.

Temuan dari penelitian ini menjelaskan upaya peningkatan kinerja pegawai dapat ditempuh dengan menumbuhkan komitmen organisasi pegawai, yaitu kekuatan relatif dari identifikasi individu dan keterlibatan dalam organisasi khusus, meliputi kepercayaan, dukungan terhadap tujuan dan nilai-nilai organisasi dan keinginan yang kuat untuk menggunakan upaya yang sungguh-sungguh untuk kepentingan organisasi dan kemauan yang kuat untuk memelihara keanggotaan dalam organisasi. Hal ini seperti yang dijelaskan oleh Robbins (2006), komitmen organsiasi merupakan suatu keadaan dimana seorang pegawai memihak pada suatu organisasi tertentu dan tujuan - tujuannya serta berniat memelihara keanggotaan dalam organisasi itu. Hal ini berdampak ketika seorang pegawai sedang menghadapi kondisi akan suatu pilihan di lingkungan eksternal, pegawai tersebut akan cenderung berpola pikir seperti perusahaan tempat dia bekerja dan secara implisit akan menunjukkan keberpihakannya atas keunggulan - keunggulan perusahaan tempat dia bekerja. Implikasi lainnya adalah seorang pegawai akan merasa memiliki tanggung jawab untuk mengembangkan perusahaannya dan dapat dilakukan dengan pengembangan kapasitas orang yang berada pada subordinatnya.

Hasil penelitian ini menjelaskan bahwa untuk meningkatkan komitmen organisasi dalam diri pegawai, dapat ditempuh dengan memperbaiki cognitive framework(kerangka kognitif) organisasi yang meliputi sikap, nilai-nilai, norma perilaku dan harapan-harapan yang disumbangkan anggota organisasi. Hal ini sejalan dengan pendapat Gomes (2003) bahwa terdapat tiga faktor yang mempengaruhi perilaku dan prestasi kerja yaitu faktor individu, faktor organisasi, dan faktor psikologis. Semakin tingginya budaya organisasi yang ditandai dengan meningkatnya profesionalisme, percaya pada rekan sekerja, dan keteraturan, akan mampu menumbuhkan kekuatan relatif dari identifikasi individu dan keterlibatan dalam organisasi khusus, meliputi kepercayaan, 
dukungan terhadap tujuan dan nilai-nilai organisasi dan keinginan yang kuat untuk menggunakan upaya yang sungguh-sungguh untuk kepentingan organisasi dan kemauan yang kuat untuk memelihara keanggotaan dalam organisasi.

\section{Pengaruh Gaya Kepemimpinan Transformasional Secara Langsung Terhadap Kinerja Pegawai \\ Hasil uji hipotesis ketiga dalam} penelitian ini menyatakan bahwa ada pengaruh positif dari gaya kepemimpinan tranformasionalsecara langsung terhadap kinerja pegawai. Semakin tinggi kepemimpinan transformasional yang mencakup upaya perbaikan organisasi Kantor Kecamatan Watukumpul,akan memiliki dampak pada peningkatan kinerja pegawai. Hasil studi ini mendukung dan membuktikan secara empiris penelitian yang dilakukan oleh Rahmawati (2010), Mondiani (2012), Trilaksono (2010), dan Fajra (2011) yang menjelaskan bahwa gaya kepemimpinan berpengaruh positif dan signifikan terhadap kinerja pegawai. Temuan penelitian ini tidak sejalan dengan hasil riset Hasanuddin (2011) dan Fajra (2011), yang menyebutkan gaya kepemimpinan berpengaruh negatif dan kurang signifikan terhadap kinerja pegawai. Gaya kepemimpinan tranformasional dalam penelitian ini memiliki pengaruh positif terhadap kinerja pegawai. Hal ini berarti pengaruh pemimpin untuk mengubah perilaku pegawai menjadi seseorang yang mampu dan bermotivasi tinggi akan melahirkan prestasi kerja yang tinggi serta bermutu untuk mencapai tujuan organisasi. Pemimpin yang memiliki gaya transformasional adalah pemimpinan yang memiliki keinginannya untuk mendahulukan kepentingan perusahaan dan kepentingan orang lain daripada kepentingannya sendiri, mampu menimbulkan inspirasi pada pegawainya, mampu mendorong pegawai untuk memikirkan kembali cara kerja pegawai dalam mencari cara-cara baru guna melaksanakan tugas-tugasnya, memperhatikan dan memperlakukan pegawai secara khusus, dan berusaha mempengaruhi karyawan dengan menekankan pentingnya nilai-nilai dan keyakinan, cita-cita dan nilai. Dengan gaya kepemimpinan tersebut maka akan mendorong motivasi pegawai untuk menghasilkan kualitas dan kuantitas kerja karyawan sesuai standar kerja yang telah ditetapkan. Hal ini seperti yang dijelaskan oleh Mangkunegara (2007) bahwa kinerja dipengaruhi faktor motivasi yang dihasilkan dari proses kepemimpinan.

\section{Pengaruh Budaya Organisasi Secara Langsung Terhadap Kinerja Pegawai \\ Hasil dari uji hipotesis keempat} dalam penelitian ini menyatakan bahwa ada pengaruh langsung positif dari budaya organisasi terhadap kinerja pegawai. Semakin tinggi budaya organisasi dibangun pada Kantor Kecamatan Watukumpul akan berdampak nyata pada peningkatan kinerja pegawai. Temuan penelitian ini sejalan dengan penelitian sebelumnya yang dilakukan oleh Rahmawati (2012), Fajra (2011), Trilaksono (2010) yang menjelaskan bahwa budaya organisasi berpengaruh positif dan signifikan terhadap kinerja pegawai. Hasil penelitian ini berlawanan dengan hasil riset Fajra (2011), dan Hasanuddin (2011) yang menunjukkan budaya organisasi bukan faktor penting yang mempengaruhi kinerja pegawai.

Budaya organisasi merupakan sikap, nilai-nilai, norma perilaku dan harapan-harapan yang disumbangkan oleh anggota organisasi. Dari hasil penelitian ini, dapat dijelaskan bahwa budaya organisasi menjadi faktor penting dalam upaya mendorong pegawai menghasilkan kreativitas, kualitas, dan kuantitas kerja sesuai standar kerja profesional masingmasing. Robbins (2006) menjelaskan perubahan budaya organisasi ke arah yang lebih baik dapat dilakukan dengan menjadikan perilaku manajemen (pejabat) sebagai model, menciptakan kebiasaan dan keyakinan sesuai budaya yang diinginkan, menciptakan dan mensosialisasikan nilainilai baru, dan meningkatkan kerja sama kelompok. Sedangkan menurut Mangkunegara (2007) kondisi organisasi secara formal dan informal seperti budaya organisasi memiliki pengaruh terhadap kinerja pegawai

\section{Kesimpulan dan Saran}

Pemerintah Kabupaten Pemalang, Kecamatan Watukumpul hendaknya dapat menerapkan gaya kepemimpinan transformasional dalam membangkitkan komitmen organisasi dan kinerja pegawai. Hal yang perlu lebih mendapat perhatian adalah pada indikator yang paling lemah 
dalam penelitian ini, yakni Idealized Influence. Langkah operasional yang dilakukan adalah dengan mendahulukan kepentingan organisasi dibandingkan kepentingan pimpinan sehingga karyawan menilai pemimpin sebagai seorang yang konsekuen mewujudkan tujuan organisasi.

Pemerintah Kabupaten Pemalang, Kecamatan Watukumpul hendaknya dapat terus memperbaiki budaya organisasi sehingga kinerja pegawai dapat terus meningkat. Hal yang perlu lebih mendapat perhatian adalah pada indikator yang paling lemah dalam penelitian ini, yakni percaya pada rekan sekerja. Langkah operasional yang dilakukan adalah antara lain dengan melakukan kegiatan outbond dimana setiap pegawai akan dilatih untuk bekerja sama dengan suasana gembira.

Pemerintah Kabupaten Pemalang, Kecamatan Watukumpul hendaknya dapat memperhatikan aspek komitmen organisasi yang paling lemah sehingga dapat mendorong kinerja pegawai, yaitu makna organisasi untuk seorang pegawai. Langkah kongkrit yang dapat dipilih adalah dengan lebih memberikan tanggung jawab kemajuan organisasi pada pegawai, ataupun mendelegasikan pekerjaan yang bersifat strategis kepada pegawai yang berkompeten.

\section{DAFTAR PUSTAKA}

Arep, I. dan Tanjung,H. 2003. Manajemen Sumber Daya Manusia. Jakarta: Universitas Trisakti.

Arikunto, S. 1998. Prosedur Penelitian Suatu Pendekatan Praktek. Jakarta: PT. Rineka Cipta.

Ferdinand,A.T.2006. Metode Penelitian Manajemen: Pedoman Penelitian Untuk Penulisan Skripsi, Tesis dan Disertasi Ilmu Manajemen.Semarang: Badan Penerbit Universitas Diponegoro

Bass,B.M. 1985. Leadership and Performance.N.Y. Free Press

Bass, B.M.. 1990. Improving Organizational Effectiveness through Transformasional Leadership. Thousand Oaks : Sage.

Bass,B.M. $1995 . \quad$ "Theory of Transformational Leadership." Leadership Quertery, 6, 463-478

Davis, K. and Newstrom, J.W. 1995. Perilaku Dalam Organisasi. Jakarta: Erlangga.

Davis, K. 1985. Human Resources and
Personnel Management. Fourth Edition. Singapore: McGraw-Hill Book Co.

Emmanuel Ogbonna and Lloyd C Harris. 2000. Leadership style, organizational culture and performance: empirical evidence from UK companies. The International Journal of Human Resource Management

Fajra,F.K. 2011. Pengaruh Gaya Kepemimpinan, Budaya Organisasi, dan Motivasi Kerja terhadap Kinerja pegawai Badan Kepegawaian Daerah Kabupaten Agam. Universitas Andalas.

Ghozali.,I. 2009. Aplikasi Multivariate Dengan Program SPSS. Badan Penerbit Universitas Diponegoro: Semarang

Gomes, F.C. 2003. Manajemen SDM. Yogyakarta: Penerbit Andi.

Hadi, S. 2000. Metodologi Research. Yogyakarta : Andi Yogyakarta.

Hasanuddin. 2011. Pengaruh Budaya Organisasi dan Kepemimpinan terhadap Motivasi Kerja serta Dampaknya pada Kinerja Organisasi (Studi Kasus Bappeda Kabupaten Aceh Besar). Universitas Syiah Kuala.

Heidrajrahcman dan Husnan Suad. 2002. Manajemen, Personalia. Yogyakarta: BPFE

Hersey, P. dan Blanchard,K. 1992. Manajemen Perilaku Organisasi : Pendayagunaan Sumberdaya Manusia, Cetakan Ketiga, Alih Bahasa Agus Dharma, Jakarta: Erlangga

Hersey. 2004. Kunci Sukses Pemimpin Situasional. Jakarta: Delaprasata

Hofstede, G. 1994. Cultures and Organization: Software of The Mind. London: Harper Collind Publisher.

Junchen,H. 2012. A Literature Review on Organizational Culture and Corporate Performance International Journal of Business Administration

Kouzes, J. M., \& Posner, B. Z. 1987. The leadership challenge: How to get extraordinary things done in organizations. San Francisco: Jossey-Bass.

Mangkunegara, AA. 2007. Manajemen Sumber Daya Manusia. cetakan Ke 
Tujuh. Bandung: PT. Remaja Rosdakarya

Margono, S. 2003. Metodologi Penelitian Pendidikan. Jakarta: PT Rineka Cipta.

Mas'ud, F. 2004. Survai Diagnosis Organisasional (Konsep dan Aplikasi). Semarang: Badan Penerbit Universitas Diponegoro.

Mondiani,T. 2012. "Pengaruh Kepemimpinan Transformasional dan Kompensasi Terhadap Kinerja pegawai PT. PLN Persero UPJ Semarang".Jurnal Administrasi Bisnis FISIP Undip. Vol I No. 1. September 2012

Nahavandi,A, dan Malekzadeh,A.R. .1993. Organizational Behaviour: The Person-Organization Fit. New Jersey : Prentice Hall.

Noe, R. A., Hollenbeck, J. R., Gerhart, B. dan Wright, P. M. 2000. Fundamental of Human Resource Management. New York: McGrawHill.

Rahmawati. 2012. Pengaruh Budaya Organisasi, Gaya Kepemimpinan, Dan Motivasi Kerja Terhadap Kinerja Dosen Di Universitas Sultan Ageng Tirtayasa. Universitas Sultan Ageng Tirtayasa

Ratnawati,I,CMT. 2012. "Analisis Pengaruh Budaya Organisasi \& Kepuasan Kerja terhadap Komitmen Organisasi Dalam Meningkatkan Kinerja Karyawan (Studi pada PT. Sido Muncul Kaligawe Semarang)." Jurnal Bisni dan Ekonomi (JEB), Vol. 19 (2), pp. 170-187

Robbins, S.P. (2006), Perilaku Organisasi, Jilid I, Edisi 9 (Indonesia), PT. Indeks Kelompok Gramedia, Jakarta.

Schein, Edgar H. 1992. Organizational Culture and Leadership. San Francisco: Jossey Bass

Soedjono. 2005. "Pengaruh Budaya Organisasi Terhadap Kinerja Organisasi dan Kepuasan Kerja Karyawan pada Terminal Penumpang Umum di Surabaya, Jurnal Manajemen \& Kewirausahaan, Vol. 7(1), pp. 2247

Siagian, Sondang P, 2007. Manajemen Sumber Daya Manusia. Jakarta: Bumi Aksara.
Sudjana. 1996. Teknik Analisis Regresi Dan Korelasi. Bandung: Tarsito.

Sugiyono. 2003. Statistika Untuk Penelitian. Bandung: Alfabeta.

Sukanto Reksohadiprodjo, T. Hani Handoko. 2000. Organisasi Perusahaan, Teori, Struktur dan Prilaku.Edisi X, Yogyakarta: Penerbit BPFE.

Sunarsih. 2001. "Kepemimpinan Transformasional Dalam Era Perubahan Organisasi." Jurnal Manajemen dan Bisnis. Vol 5 No.2. Desember 2001

Mondiani,T. 2012. "Pengaruh Kepemimpinan Transformasional dan Kompensasi Terhadap Kinerja pegawai PT. PLN Persero UPJ Semarang".Jurnal Administrasi Bisnis FISIP Undip. Vol I No. 1. September 2012

Trilaksono,B.P. 2010. Pengaruh Budaya Organisasi, Kepemimpinan, dan Motivasi Kerja Terhadap Kinerja pegawai Di Cipaganti Group. Universitas Dian Nuswantoro.

Umar,H. 2008. Desain Penelitian MSDM dan Perilaku pegawai. Jakarta: PT Rajagrafindo Persada.

Veithzal, R. 2004. Manajemen Sumber Daya Manusia Untuk Perusahaan. Cetakan Pertama . Jakarta: PT. Raja Grafindo.

Widodo. 2011. Pengaruh Gaya Kepemimpinan, Budaya Organisasi, dan Motivasi Kerja Terhadap Kinerja Guru. Yayasan BPK Penabur.

Yukl, G. 1995. Kepemimpinan Dalam Organisasi. Terjemahan. Jakarta : PT. Indeks 